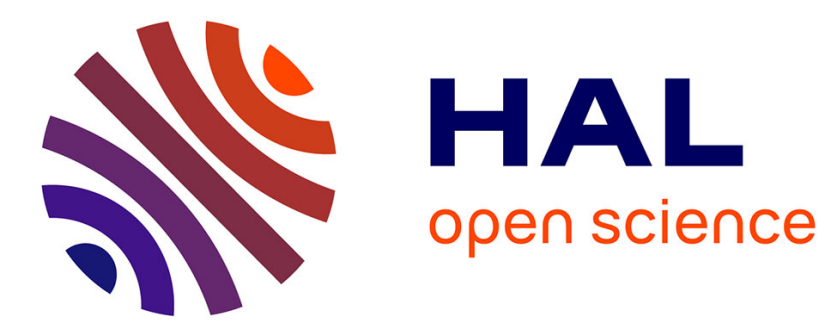

\title{
STEM imaging to characterize nanoparticle emissions and help to design nanosafer paints
}

Martin Morgeneyer, Olivier Aguerre-Chariol, Christophe Bressot

\section{To cite this version:}

Martin Morgeneyer, Olivier Aguerre-Chariol, Christophe Bressot. STEM imaging to characterize nanoparticle emissions and help to design nanosafer paints. Chemical Engineering Research and Design, 2018, 136, pp.663-674. 10.1016/j.cherd.2018.06.013 . ineris-01875963

HAL Id: ineris-01875963

https://hal-ineris.archives-ouvertes.fr/ineris-01875963

Submitted on 3 Aug 2021

HAL is a multi-disciplinary open access archive for the deposit and dissemination of scientific research documents, whether they are published or not. The documents may come from teaching and research institutions in France or abroad, or from public or private research centers.
L'archive ouverte pluridisciplinaire HAL, est destinée au dépôt et à la diffusion de documents scientifiques de niveau recherche, publiés ou non, émanant des établissements d'enseignement et de recherche français ou étrangers, des laboratoires publics ou privés. 


\section{STEM imaging to characterize nanoparticle emissions and help to design nanosafer paints}

Authors:

Morgeneyer, Martin

Génie de Procédés Industriels

Sorbonne Universités, Université de Technologie de Compiègne (UTC)

Compiègne, France

martin.morgeneyer@utc.fr

Aguerre-Chariol, Olivier

Direction des Risques Chroniques

Institut National de l'Environnement Industriel et des Risques (INERIS)

Verneuil en Halatte, France

olivier.aguerre-chariol@ineris.fr

Bressot, Christophe

Direction de risques chroniques

Institut National de l'Environnement Industriel et des Risques (INERIS)

Verneuil en Halatte, France

christophe.bressot@ineris.fr

\section{CORRESPONDING AUTHOR}

Bressot, Christophe

christophe.bressot@ineris.fr

\section{$\underline{\text { Highlights }}$}

- Tests on two weathered paints have been performed.

- releases of (sub)micronic $\mathrm{NOAAs}$ of $\mathrm{TiO}_{2}$ with few $\mathrm{NP}$ of nano- $\mathrm{TiO}_{2}$ are observed.

- $\quad$ STEM, highlights the presences of $\mathrm{Si}$ and $\mathrm{Zn}$ in the form of isolated particles.

- Ti is mainly present in the form of micronic nano-objects.

- However, $\mathrm{Ti}$ is also rarely observed in free nano- $\mathrm{TiO}_{2}$ forms.

\section{Abstract}

The growing use of common consumer goods made of materials containing nanoparticles could increase the exposure of consumers to these substances during their lifecycle. In view of evaluating this risk a setup and experimental protocol of weathering and mechanical solicitation was realized. Tests on two paints were performed. One of them releases mainly submicronic sized nanostructured nano-objects and their agglomerates and aggregates (NOAAs) of titanium dioxide in presence free nano- $\mathrm{TiO}_{2}$. The formulation of the emissive paint is under question. 


\section{Keywords:}

Weathering, aerosol emission, abrasion, depolluting nanomaterial, nano- $\mathrm{TiO}_{2}$, STEM, TEM. 


\section{Introduction}

Nanomaterials are present in a growing number of products with new, innovative properties (Mitrano et al., 2015; Piccinno et al., 2012). Numerous self-cleaning or antibacterial coatings have titanium dioxide properties in nanometric form (Chapman et al., 2012).

The growing use of these common consumer goods could increase the exposure of consumers to these substances during their lifecycle. Indeed, the NP incorporated in these products are likely to be discharged in free, aggregated, agglomerated or composite form during their entire lifecycle, depending on the strength of the bond between the nanofiller and the matrix (Piccinno et al., 2012; Shandilya et al., 2015).

Effective risk management requires one to equally consider NP exposure, which has thus far been little explored, as it represents only $16 \%$ of the entirety of studies bearing on NP (Froggett et al., 2014). Moreover the exhaustive study of routes of human exposure to NP concludes that risk by inhalation is greater than through the skin or by ingestion (Daigle et al., 2003).During the mechanical solicitation of nanomaterial, potential discharges have already been observed from different materials, such as textiles or antibacterial bandages (Scheringer et al., 2014), but also coatings (Kaegi et al., 2010; Kaegi et al., 2008).

NP exposures from paints belong to a particular field of exposure. These NP are used frequently to depollute the air from Volatile Organic Compounds (VOCs) or Nitrogen oxides (NOXs) and are specially designed to do so (Bartolomei et al., 2014; Hincapie et al., 2015; Lazaridis et al., 2015). Many studies performed on aerosols generated with paints containing nanoparticles exhibit in general a low level of emission. Some authors highlight a weak exposure mainly based on composite forms with rare free particles of nano- $\mathrm{TiO}_{2}$ (Al-Kattan et al., 2015; Al-Kattan et al., 2014; Zuin et al., 2013). A counting similarity of the aerosols generated by paint abrasion with or without nano-filler is observed (Koponen et al., 2011). Based on these data, some authors, suggest that nanorisks are constant because no evolution of the ultrafine fraction of the emissions have been identified (Kaiser et al., 2013).

However, nanotoxicological risks of pristine nanoparticles or nanofibers are documented (Handy and Shaw, 2007; Maynard et al., 2006; Pirela et al., 2015) and raise particular concern for human health. A notable case similar to asbestos exposure was reported after exposure to long, rigid carbon nanotubes (Poland et al., 2008). The precise evaluation of effects due to the nanometric sizes of objects is still under investigation (Donaldson and Poland, 2013; Elsaesser and Howard, 2012).

Moreover the specific case of the toxicity of nanotitanium dioxide nanoparticles is well documented (Hong et al., 2017; Shi et al., 2013) and gives rise to a high level of concern. $\mathrm{NIOSH}$ based on literature identified documented toxicological evidence of i) Inflammation of the pulmons: The substance can lead to a pulmonary inflammation and also aggravate previous diseases. ii) Genotoxicity: The material can sometimes damage DNA (e.g., nano$\mathrm{TiO}_{2}$ exposed to UV light). iii) Carcinogenicity: $\mathrm{NIOSH}$ determined that nano- $\mathrm{TiO}_{2}$ inhalation caused by occupational exposure should be considered as a potential occupational carcinogen. iv) Organ effects. A low exposure levels is observed due to a nano- $\mathrm{TiO}_{2}$ accumulating particularly in the liver (Shi et al., 2013). NIOSH (NIOSH 2011) recommend for nano- $\mathrm{TiO}_{2}$ a $\mathrm{REL}$ (Recommended Exposure Limits) at an average concentration of $0.3 \mathrm{mg} / \mathrm{m}^{3}$ throughout a time weighted of $8 \mathrm{~h} /$ day during $40 \mathrm{~h}$ work week while the Japan Society for Occupational Health (JSOH) propose a OEL (Occupational Exposure Limit) at $0.6 \mathrm{mg} / \mathrm{m}^{3}$ (Nakanishi and Gamo, 2016). 
In the specific case of paint debris no inflammations, oxidative stress, or genotoxic effects of nanoparticles from paint wear have been identified (Mikkelsen et al., 2013; Saber et al., 2012). However, the elements of emission such as aggregate vs. agglomerate are not considered. Furthermore, ecotoxic impact of paint nanoparticles on environment, i.e. salad, has been studied. No phytotoxic effects have been highlighted (Larue et al., 2014).

The types of the emissions i.e. the size, the shape and the chemical composition of particles, play presumably a critical role in the exposures and in the nanotoxicological risks and is affected by the paint formulation, the weathering and the mechanical solicitation of the samples.

Regarding the chemical composition and the shape of nanofillers some works aimed to compare dust released during mechanical abrasion of nanocomposites to a conventional paint. This was performed by sanding and/or sawing CNT epoxy-based nanocomposites and boards painted with paints containing different amounts of nano-sized titanium dioxide $\left(\mathrm{TiO}_{2}\right)$ in their formulation. Particles emitted from nano-composites with CNTs presented fiber-shaped protrusions likely caused by the presence of embedded CNTs, although no free isolated CNTs were found in any of the dust samples. (Gomez et al., 2014).

Despite the huge presence of nano- $\mathrm{TiO}_{2}$ in the paint production (Piccinno et al., 2012), no tests have been performed to assess the aerosol modification due to the weathering effects on a paint containing a nanofiller like nano- $\mathrm{TiO}_{2}$ because of the difficulty to distinguish a nano- $\mathrm{TiO}_{2}$ from a nano-sized of conventional formulation. Indeed, paints showed a high concentration of nanometric Ti (named nano-pigments), which is the main component of these suspensions. The release from paints will also contain particles, NOAA, composites with nano-pigments. For example, Gomez et al found between $32 \%$ to $80 \%$ of the particles containing Ti in the samples (Gomez et al., 2014).

By using STEM microscopy in nanomaterial framework, we hope to characterize the nanoscale, of samples, providing important insights into the properties and behaviour of materials. The images that are obtained could be more representative in term of presence of chemical compounds in the specimen. Indeed, bigger surfaces are tracked by STEM than a simple TEM analysis.

There is growing interest in reducing hazard through appropriate design and applications of engineered nanomaterials. The design rule involves five fundamental principles, summarized by the acronym SAFER, with $S$ for size, surface, or structure, $A$ for alternative materials, $\mathrm{F}$ for functionalization, $\mathrm{E}$ for encapsulation and $\mathrm{R}$ for reduce the quantity. These principles focus on aspects such as modifying physical-chemical characteristics of the material to decrease the hazard, considering alternative materials, and enclosing the material within another, less hazardous, material (Morose, 2010). These principles should take consequently into account the weathering effects to develop the appropriate products leading to the lowest possible exposure.

We define consequently a setup of weathering and solicitation to obtain the worst-case scenario described in the literature i.e. a long-term weathering of 7 months and an abrasion test to simulate a mechanical solicitation in the real life of commercial paints with nano- $\mathrm{TiO}_{2}$. This kind of abrasion test has been used in many cases like for investigating the complete stress state during abrasion (Morgeneyer M., 2014). 


\section{Materials and methods}

\section{Samples:}

The materials studied were very varied in their formulations and properties, and required adapted means of investigation. P2 paint have depolluting properties and are for exterior application, whereas P1 paint has identical properties, but is used in the interior of buildings. All these products share a probable nano- $\mathrm{TiO}_{2}$ nanofiller. As not a single manufacturer provides a formula nor even information about the presence of nanoparticles, a size description by CPS granulometry and dispersion composition by TXRF before application are thereby required to allow a comparison between NP emissions and product formulation.

The commercial availability of photocatalytic paints is more recent. In this study, those photocatalytical paints have been selected in which we found nanoparticles. One of the paints is sold as indoor air cleaning, the other as reducing (outdoor) NOx. For both paints, the chosen substrate is a $11 \mathrm{~cm} \times 5 \mathrm{~cm} \times 5 \mathrm{~cm}$ masonry brick, mainly composed of aluminosilicate and to a lesser extend calcium. The commercial information of these products is summarized in table 1. 


\section{Table 1 : Description of the paints}

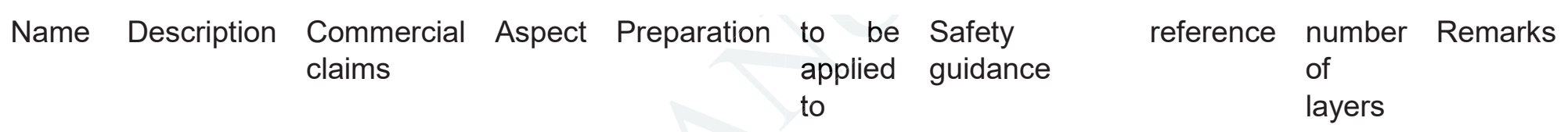

\begin{tabular}{|c|c|c|c|c|c|c|c|c|c|c|}
\hline $\begin{array}{l}\text { Paint } \\
1\end{array}$ & $\begin{array}{l}\text { Indoor } \\
\text { paint }\end{array}$ & $\begin{array}{l}\text { Cleaning of } \\
\text { indoor air }\end{array}$ & $\begin{array}{l}\text { Very } \\
\text { mat } \\
\text { white }\end{array}$ & $\begin{array}{l}\text { ready } \\
\text { use } \\
15 \mathrm{~L}\end{array}$ & for & $\begin{array}{l}\text { any } \\
\text { support }\end{array}$ & $\begin{array}{l}\text { Environmental } \\
\text { and sanitary } \\
\text { declaration } \\
\text { No individual } \\
\text { respiratory } \\
\text { protection } \\
\text { equipment is } \\
\text { necessary } \\
\text { unless } \\
\text { insufficient } \\
\text { aeration } \\
\text { (mask with } \\
\text { particle filter } \\
\text { P2) }\end{array}$ & $\mathrm{P} 1$ & 2 & $\begin{array}{l}\text { Photocatalysis } \\
\text { presence of nano- } \mathrm{TiO}_{2} \text { with primary } \\
20 \mathrm{~nm} \text { particles (sized by } \mathrm{TEM} \\
\text { imaging) composition } \mathrm{TiO}_{2} \text {, } \\
\text { polymers, } \mathrm{CaCO}_{3} \text {, talcum, water, } \\
\text { additives, } \\
\text { preservatives }\end{array}$ \\
\hline
\end{tabular}


necessary

unless

insufficient

aeration

(mask with

particle filter

P2) 
Paints 1 and 2 have been provided by the same manufacturer but differ significantly with respect to the primary particles of nano- $\mathrm{TiO}_{2}$ : $\mathrm{P} 1$ is made up with $20 \mathrm{~nm}$ sized primary particles while $\mathrm{P} 2$ involved nano- $\mathrm{TiO}_{2}$ of $7 \mathrm{~nm}$ size(see Figure 1) b).

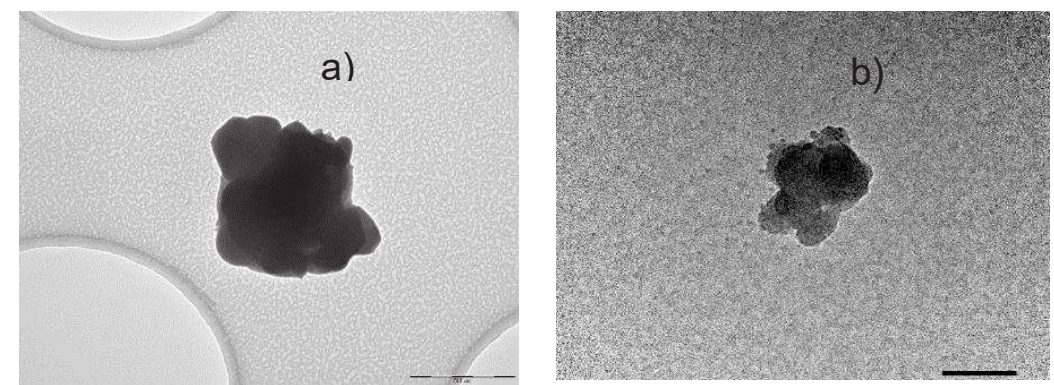

Figure 1 a) submicronic particles from P2, scale $200 \mathrm{~nm}$. b) Nano- $\mathrm{TiO}_{2}$ particles around a NOAA are detected on P2 samples. They are made of isolated primary particles of 7 $\mathrm{nm}$, scale $100 \mathrm{~nm}$.

\section{Instrumentations:}

\subsection{Granulometric characterization methods in liquid phase}

The CPS granulometer with a centrifugal disc is a dimensional analytical system intended to obtain the size distribution of particles of which the size is between 0.005 and 50 microns. The apparatus distinguishes particles in relation to their size by centrifugal sedimentation in a liquid medium. A density gradient within the liquid allows stabilised sedimentation. The particles settle inside a disc. This instrument is adapted to the study of polydisperse suspensions, unlike DLS (Dynamic Light Scattering), of which the optimal use is the characterization of submicronic monodisperse particles (Gregory, 2005; Mahl et al., 2011).

Products to be deposited on surfaces such as paints with possibly polydisperse distributions are preferentially characterized by CPS granulometry. In our conditions and with the agreement of with the CPS instruments Europe prescription (see (CPS Instruments Europe, 2004)), the protocol necessitates a sucrose gradient between $8 \%$ à $24 \%(\mathrm{w} / \mathrm{w}$ ), a fluid density estimated to $1.045 \mathrm{~g} / \mathrm{ml}$, a speed of rotation equal to 3948 RPM, a dilution factor of $1 / 100$ and a size calibration standard at $0.4783 \mu \mathrm{m}$ before each test with reference calibration of polyvinyl chloride latex.

\subsection{TXRF analytical methods to obtain elemental composition}

The Total Reflection X-ray Fluorescence (TXRF) S2 PICOFOX apparatus is designed to determine the elemental composition of materials that can be prepared in thin layers on a Plexiglas or quartz specimen holder. TXRF is an analytical technique allowing a quantification of chemical elements $(Z$ (atomic number) $>\mathrm{Na}$ ) by internal calibration with gallium (De La Calle et al., 2013; Towett et al., 2013). In the presence of turbid dispersions, strong agitation of the samples allows one to obtain reproducible results (De La Calle et al., 2013). In our tests, sonication of the tested dispersions allowed us to obtain reproducible compositions.

\subsection{Weathering method}

$\mathrm{P} 1$ and $\mathrm{P} 2$ have been rolled (two layers) on a commercial plain masonry brick $(11 \mathrm{~cm} \times 5$ $\mathrm{cm} \times 5 \mathrm{~cm}$ ). The samples All of the samples were weathered 7 months according to 
standardised prescriptions (NF EN ISO 16474-1, 2014). A precise description of the method used and preliminary results were provided in a reference above (Shandilya et al., 2015), (Bressot et al., 2017) By using xenon arc lamps, the effect of sunlight is simulated in an intensified state, which is also referred to as being accelerated. The regular water spray inside the chamber simulates rain. When it rains inside the chamber, the lamp switches off automatically and vice-versa. The temperature can also be regulated inside the chamber, thus corresponding to temperatures from room temperature to very hot climate conditions of $48^{\circ} \mathrm{C}$.

\subsection{TABER abrasion method}

This standardised abrasion stress method applied to the paints was copiously described in numerous previous publications (Bressot et al., 2018; Bressot et al., 2017; Shandilya et al., 2015). The stress protocol entails linear abrasion of a sample for 10 minutes. An H22 abrasive $\left(\mathrm{TABER}^{\odot}\right.$ ) then rubs back and forth over a $76.2 \mathrm{~mm}$ distance at a speed of 60 cycles per minute, generating an aerosol that is detected and characterized by a Transmission Electronic Microscope (TEM), an Aerodynamic Particle Sizer (APS) and a Scanning Mobility Particle Sizer (SMPS).
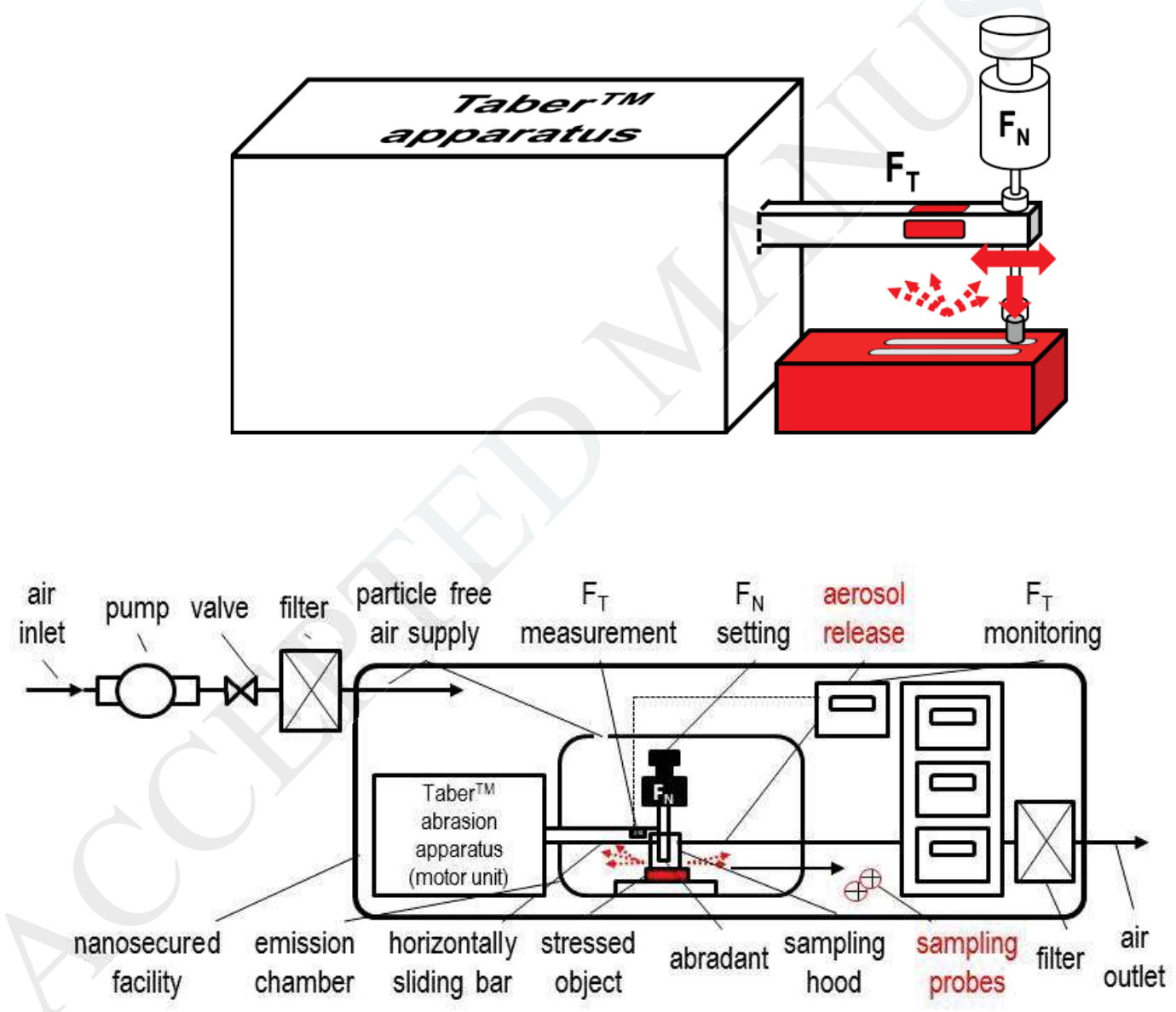

Figure 2: The taber linear abrasion apparatus (top) and the experimental set-up of the Taber 5750 linear abrasion apparatus located in an emissionchamber with the relevant instrumentation to characterized the emissions (bottom). FT: Tangential Force, FN: for Normal Force.

\section{Measurement}


The Taber device is enclosed in an emission chamber $(0.5 \mathrm{~m} \times 0.3 \mathrm{~m} \times 0.6 \mathrm{~m})$ and located in a nanosecured fume hood. The safety equipment is described in the literature (Le Bihan O. et al., 2014). The test conditions are identical to previous article (Bressot et al., 2017). The particles collected on the TEM grid (Model S143-3; Quantifoil Micro Tools GmbH Germany) using Mini Particle Sampler (MPS) are analyzed with a Transmission Electron Microcopy (TEM, Model CM12; Philips, Netherlands). Scanning Transmission Electron Microscopy (STEM) analysis are performed on JEOL JEM 1400 Plus microscope working at $120 \mathrm{kV}$ and coupled with an Energy-Dispersive X-ray Spectroscopy (EDS) (surface $100 \mathrm{~mm}^{2}$ ) using OXFORD AZTEC software.

\subsection{Results of granulometry in liquid phase of paints}

The study by centrifugal sedimentation (CPS) before application of products containing nanoparticles demonstrated the existence of monodispersed nanometric products of which the principal mode was inferior to $40 \mathrm{~nm}$ (Figure 3). The principal mode of P1 obtained by centrifugation are $32 \mathrm{~nm}$ but P2 give rise to bimodal size distribution with 116 $\mathrm{nm}$ and $402 \mathrm{~nm}$ (Figure 3).

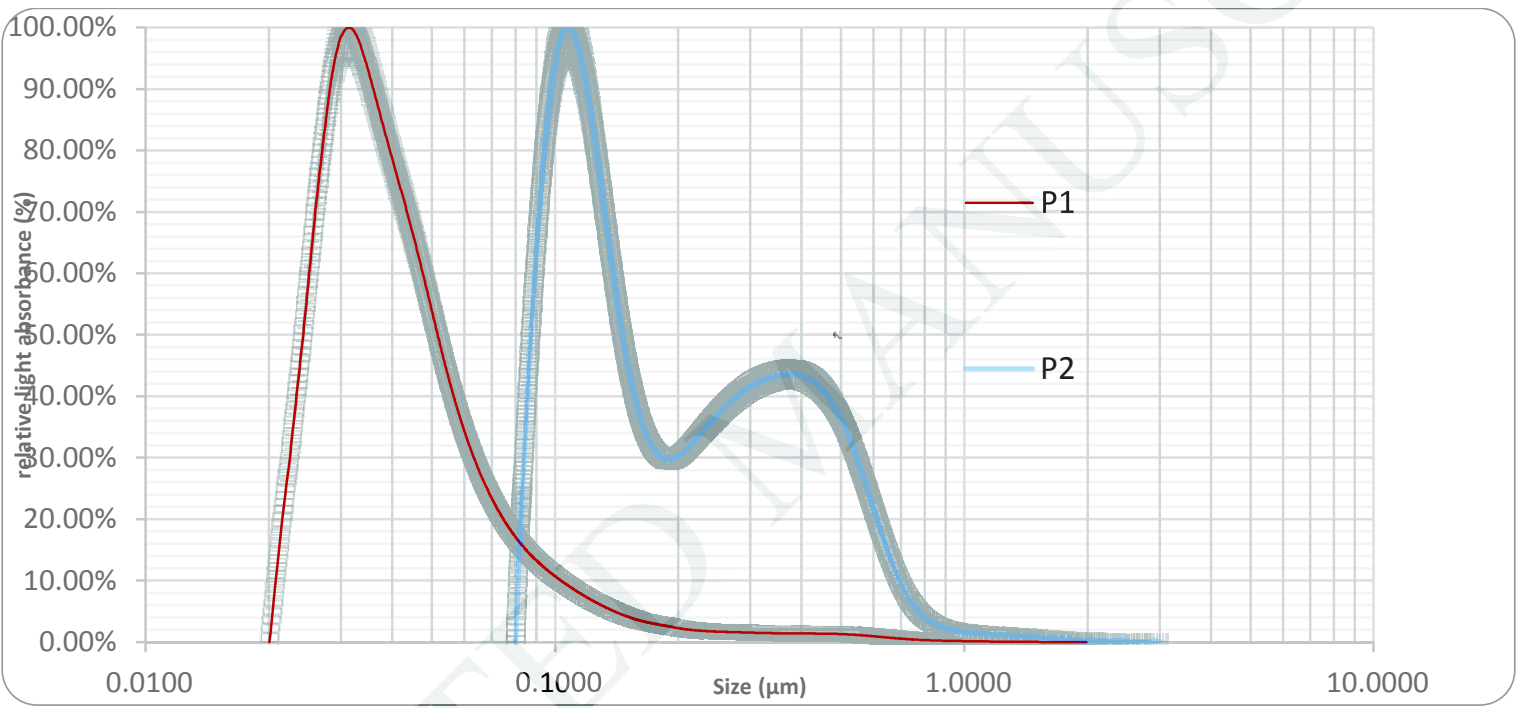

Figure 3: Size distribution of paints P1, P2 Average of 2 trials obtained by CPS and standard deviation associated to the data.

\subsection{Elemental composition results obtained by TXRF}

The compositions obtained of the different paints are presented in Table 2 respectively. The compounds of the first table contain primarily the element Ti. Paints P1 and P2 contain, besides high concentrations of the element $\mathrm{Ti}$, numerous other elements in significant quantities, such as $\mathrm{Si}, \mathrm{Zn}$ and $\mathrm{V}$. As a reminder, the organic formulation $(\mathrm{H}, \mathrm{C}$, $\mathrm{N}, \mathrm{O}$ ) cannot be determined by TXRF.

Table 2: Composition of paints (w/w). Average of 4 tests analysed by TXRF 


\begin{tabular}{lrrrrrrrrr}
\hline & Si & $\mathbf{S}$ & $\mathbf{C l}$ & $\mathbf{K}$ & $\mathbf{C a}$ & $\mathbf{T i}$ & $\mathbf{V}$ & $\mathrm{Fe}$ & $\mathbf{Z n}$ \\
\hline $\mathrm{P} 1 \mathrm{mg} / \mathrm{L}$ & $\mathbf{4 5 1 . 4}$ & 15.1 & 7.3 & 19.0 & 11.4 & $\mathbf{1 0 3 4 . 7}$ & 0.1 & 6.9 & 0.0 \\
$\%(\mathrm{w} / \mathrm{w})$ & $\mathbf{2 9 . 2 \%}$ & $1.0 \%$ & $0.5 \%$ & $1.2 \%$ & $0.7 \%$ & $\mathbf{6 6 . 9} \%$ & $0.0 \%$ & $0.4 \%$ & $0.0 \%$ \\
$\mathrm{P} 2 \mathrm{mg} / \mathrm{L}$ & $\mathbf{1 4 3 7 . 3}$ & 80.1 & 7.1 & 12.0 & 15.1 & $\mathbf{9 2 6 . 3}$ & 3.5 & 0.0 & $\mathbf{1 3 1 . 3}$ \\
$\%(\mathrm{w} / \mathrm{w})$ & $\mathbf{5 5 . 0}$ & $3.1 \%$ & $0.3 \%$ & $0.5 \%$ & $0.6 \%$ & $\mathbf{3 5 . 4}$ & $0.1 \%$ & $0.0 \%$ & $\mathbf{5 . 0} \%$ \\
\hline
\end{tabular}

\subsection{Spraying forms}

Paint spraying and particle collection make possible an analysis of generated NOAA of P1 or P2. The sprayed NOAAs from P1 have visible nanostructured parts (Figure 4) with primary particles of $20 \mathrm{~nm}$ size, while NOAA from P2 having in appearance no nanostructured parts. Some isolated primary particles of P2 are also estimated to $7 \mathrm{~nm}$ size.

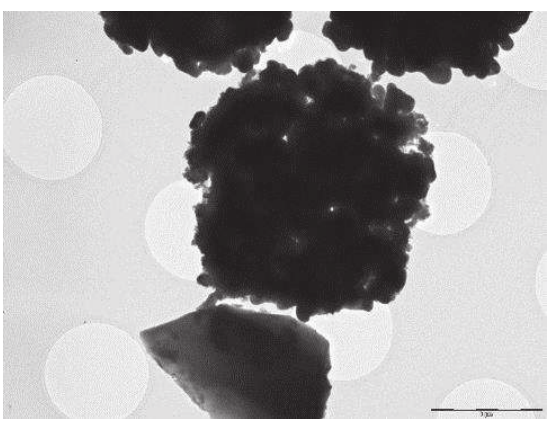

Figure 4 : NOAA from P1 with nanostructured cluster. Scale $1 \mu \mathrm{m}$.

\section{Results}

\subsection{Emissivity under abrasion of paints}

While emissions produced by abrasion of paint $\mathrm{P} 1$ before or after weathering are practically non-existent, paint P2 gave off significantly more emissions after accelerated 7month weathering. This increase in quantity is found for all sizes, but particularly for objects with a diameter of less than $30 \mathrm{~nm}$ (Figure 5). Regarding the P2 emission under abrasion, the peaks between $100-600 \mathrm{~nm}$ observed in the unweathered P2 are slightly accentuated and shifted at 111, 264, 327, $437 \mathrm{~nm}$ with the weathered P2. Moreover, the weathering process affects mainly the emissions below $100 \mathrm{~nm}$ : a big peak appeared at $21 \mathrm{~nm}$, in presence or lower peaks at $44 \mathrm{~nm}$. 


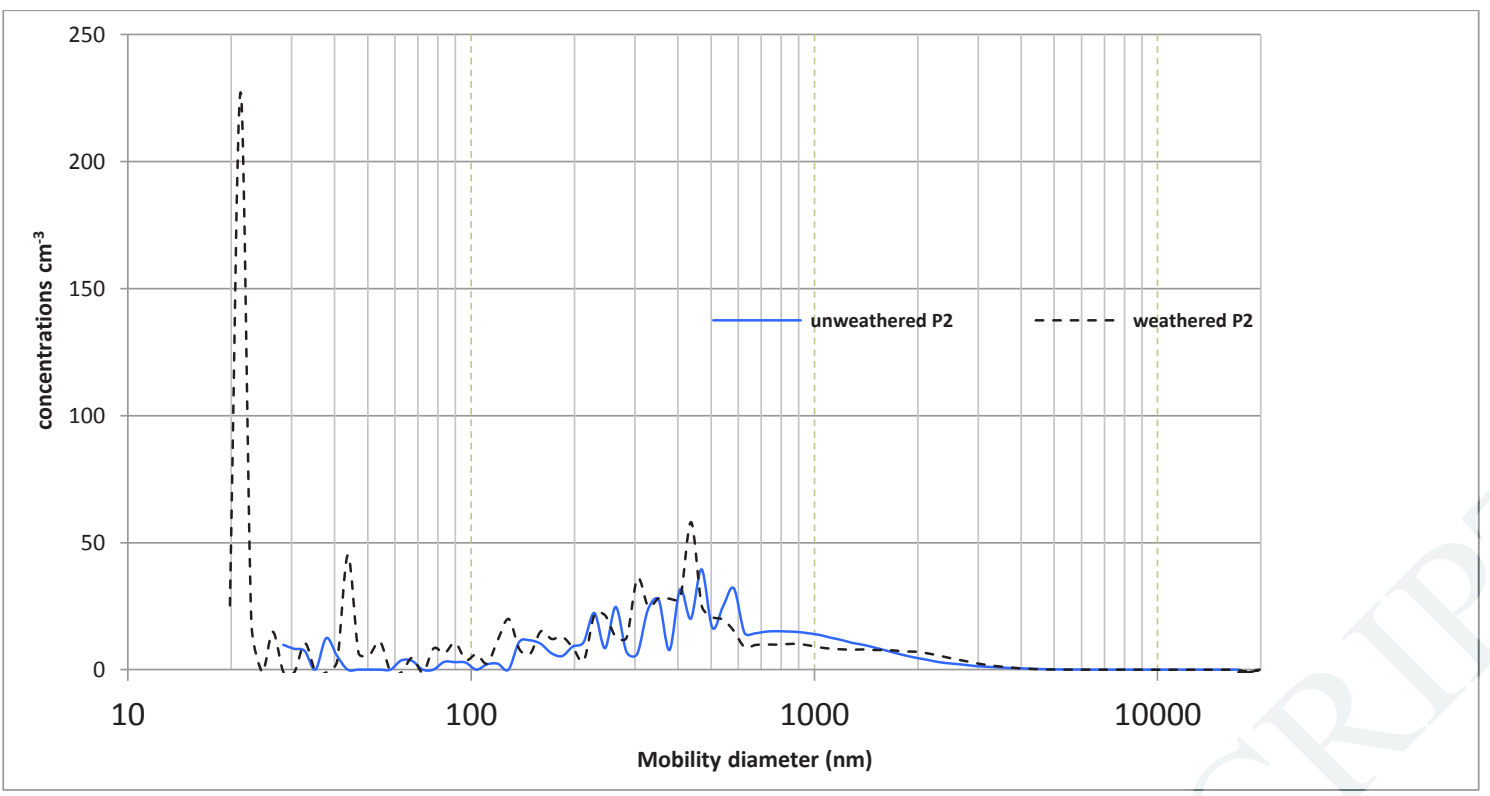

Figure 5: Emission $\left(\mathrm{cm}^{-3}\right)$ P2 weathered/unweathered from abrasion by TABER test of 60 cycles per minute. Average of ten trials by SMPS/APS coupled measurement. $X$-axis on logarithmic scale. Five SMPS scans of 2 minutes each have been used for the average. The background noise is approximately equal to $0 \# / \mathrm{cm}^{3}$ before each test.

\section{TEM results:}

$\mathrm{NP}$ and NOAA smaller than $100 \mathrm{~nm}$, principally made up of nano- $\mathrm{TiO}_{2}$, are also detected in the unweathered samples of $\mathrm{P} 2$ (see Figure 6 a). The nano- $\mathrm{TiO}_{2}$ are essentially observed in the form of nano- $\mathrm{TiO}_{2}$ composites of paint / aluminosilicate (Figure $6 \mathrm{~b}$ ). Composites contain up to $20 \%$ of titanium and lower concentrations of Zn (see Figure 6 c). No free particles of nano- $\mathrm{TiO}_{2}$ are detected on the samples.

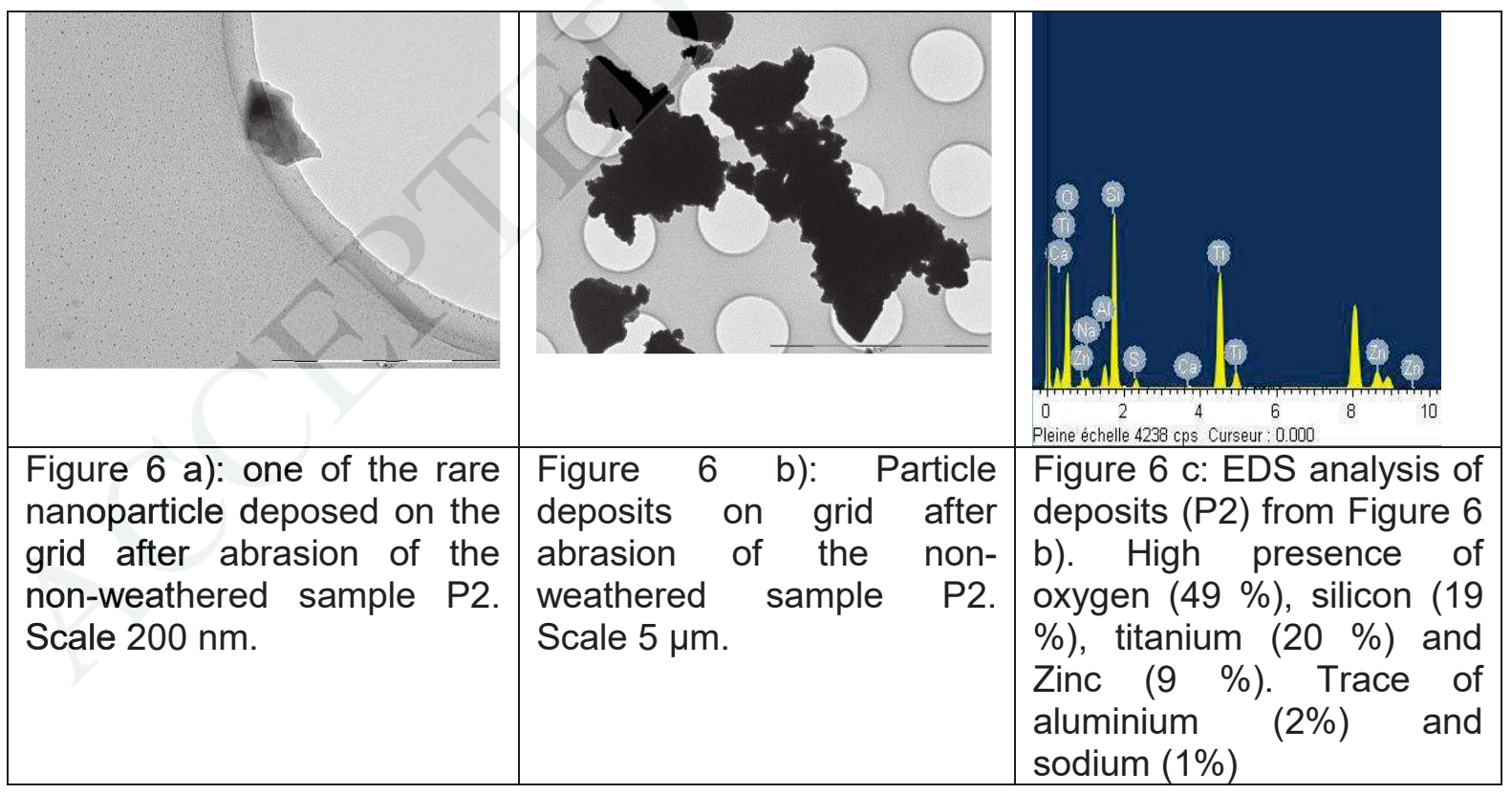




\subsection{Emissivity under stress of paints after weathering}

Compared with an abrasion of a masonry brick published in a previous work (Morgeneyer M., 2014), we observe many changes due to the weathered paint. After weathering collected the objects are indeed dominated in number by particles of approximately $20 \mathrm{~nm}$ made of $\mathrm{Ti}$ and $\mathrm{O}$. the shape looks like nano-pigment (quasi spherical particle see Figure 7) of titanium oxide or nano- $\mathrm{TiO}_{2}$ (more irregular shape, see Figure $9 \mathrm{a}$ and $b$ ). For nano$\mathrm{TiO}_{2}$, NOAA's of $14 \mathrm{~nm}+/-2 \mathrm{~nm}$ with elemental particle size of $7 \mathrm{~nm}$ (average on 20 elementary particles) dominate the sample. Isolated nanoparticles of nano- $\mathrm{TiO}_{2}$ are also present on the grid. Regarding the chemical compounds in the objects whatever the forms like nano-pigments, nano- $\mathrm{TiO}_{2}$, NOAA or composites $\mathrm{Ti}$ is the main element and is between $6 \%$ to $60 \%$ of the total. Silicon and zinc was also measured in these objects. High concentrations of $\mathrm{Ti}$ and $\mathrm{Zn}$ were measured within these nanostructured parts, formed of nano- $\mathrm{TiO}_{2}$. Some NOAA of $\mathrm{TiO}_{2}$ below $100 \mathrm{~nm}$ (Figure 11) or submicronic (Figure $11 \mathrm{a}$ and $\mathrm{c}$ or Figure 12) or micronic (Figure 13) composites are also detected.

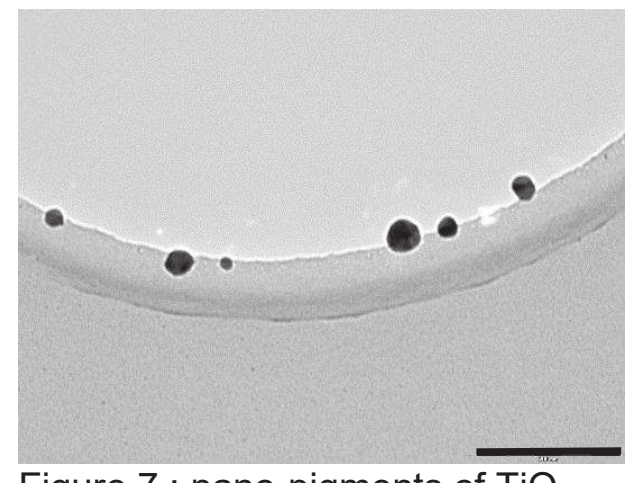

Figure 7 : nano-pigments of $\mathrm{TiO}_{2}$ presents on the sample. Scale 200 $\mathrm{nm}$.
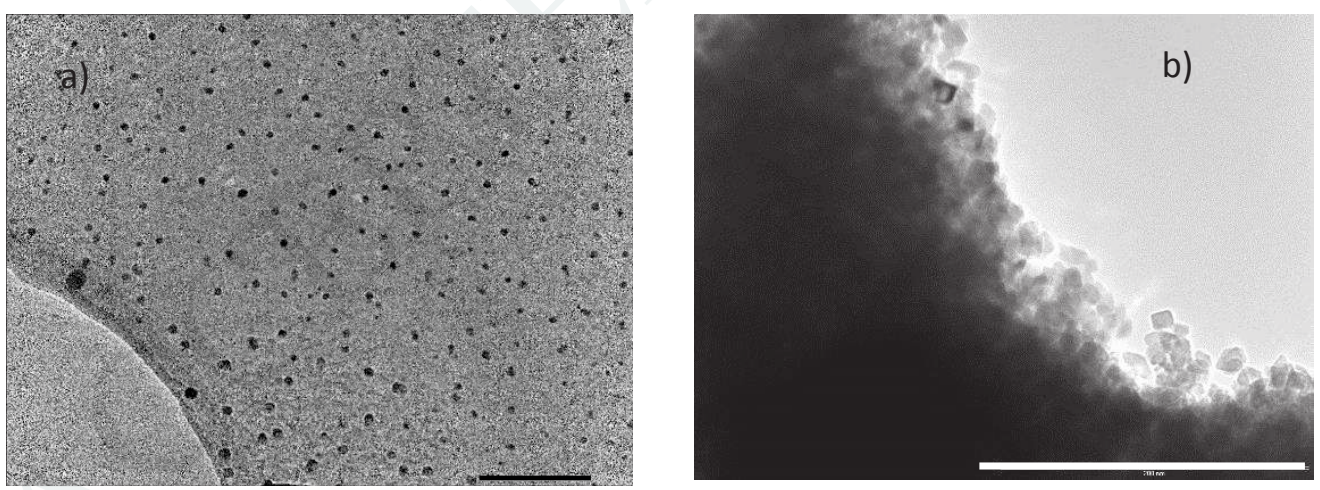

Figure 8 a) nano- $\mathrm{TiO}_{2}$ particles $(7-30 \mathrm{~nm})$ nano-pigment and particles of $\mathrm{SiO}_{2}$ presents on the sample. Scale $100 \mathrm{~nm}$. b) under agglomerate form, nano- $\mathrm{TiO}_{2}$ shape is also irregular compared to nano-pigment. Scale $200 \mathrm{~nm}$. 


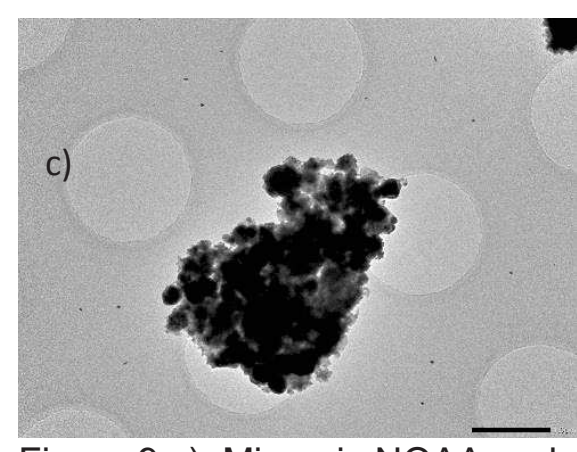

Figure $9 \mathrm{c})$ : Micronic NOAA and nano- $\mathrm{TiO}_{2}$, or nano-pigment.

Scale $1 \mu \mathrm{m}$.

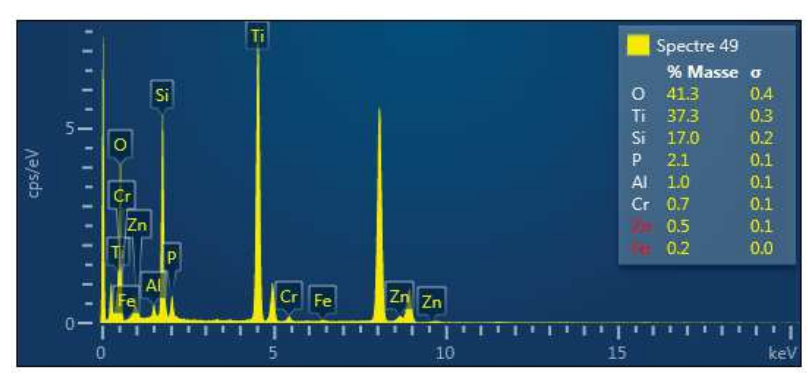

Figure 10 : EDS analysis of the Figure $9 \mathrm{c}$ )

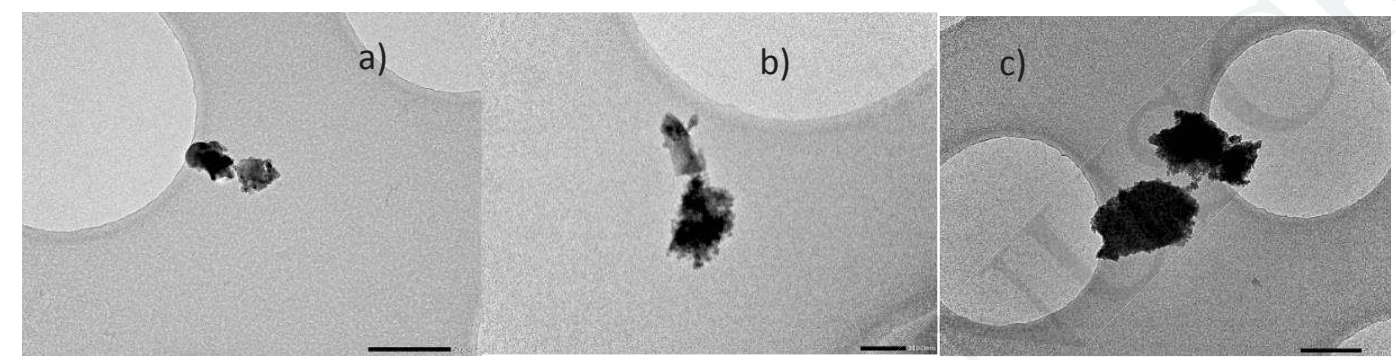

Figure 11 : NOAA of $\overline{\mathrm{TiO}_{2}}(\sim 100 \mathrm{~nm}$ size $)$ and debris of paint matrix are detected among collected objects. a) scale $500 \mathrm{~nm}$, b) scale $300 \mathrm{~nm}$ and c) scale $500 \mathrm{~nm}$.

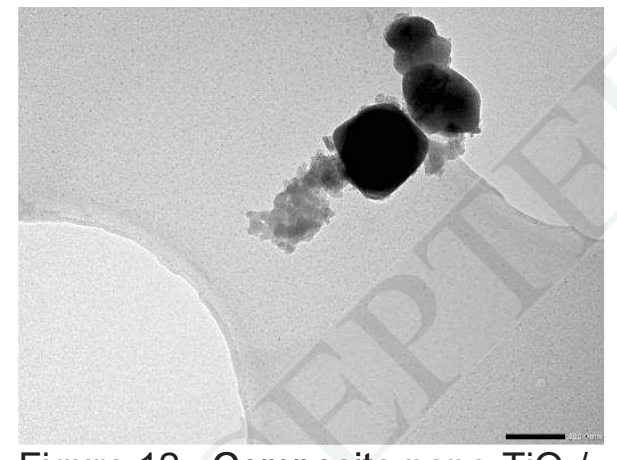

Figure 12 : Composite nano- $\overline{\mathrm{TiO}}_{2} /$ brick matrix. Scale $200 \mathrm{~nm}$ 


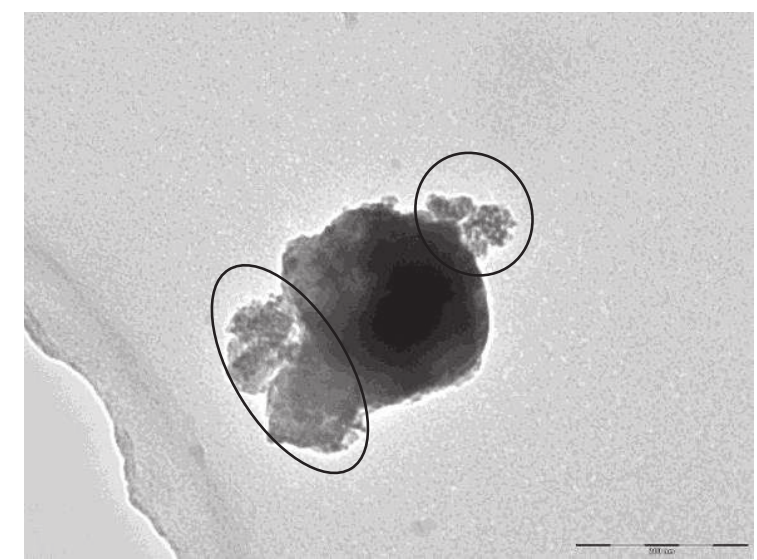

Figure 13 : Composite with a high $\mathrm{Ti}(60 \%)$ and $\mathrm{O}(31 \%)$ and $\mathrm{Si}(7 \%)$ mass. The nanostructured zones are circled. Scale: 200 $\mathrm{nm}$.

Table 3 summarizes the data obtained from the trials and the observed objects found on the TEM grid. Few objects -generally submicronic and irregular- are observed on grids except for weathered P2 where objects mainly nanometric are detected but also few submicronic and micronic NOAA or composites.

Table 3: Summary of TEM analysis and EDS microanalysis for the samples of bricks; $Y=$ yes; $\mathrm{N}$ = no; - = very low; +/-= low + =high; ++ very high; N/A = not applicable

\begin{tabular}{|c|c|c|c|c|c|c|c|c|c|}
\hline $\begin{array}{l}\text { referenc } \\
\text { e }\end{array}$ & $\begin{array}{l}\text { agi } \\
\text { ng }\end{array}$ & $\begin{array}{l}\# \\
\text { lay } \\
\text { ers }\end{array}$ & $\begin{array}{l}\text { presen } \\
\text { ce of } \\
\text { object } \\
\text { on } \\
\text { mesh }\end{array}$ & $\begin{array}{l}\text { charg } \\
\text { ed } \\
\text { grid }\end{array}$ & $\begin{array}{l}\text { Presence } \\
\text { of a } \\
\text { nanometr } \\
\text { ic fraction }\end{array}$ & $\begin{array}{l}\text { Presence } \\
\text { of a sub- } \\
\text { micronic } \\
\text { fraction }\end{array}$ & $\begin{array}{l}\text { Presence of a } \\
\text { fraction }>1 \\
\mu \mathrm{m} .\end{array}$ & $\begin{array}{l}\text { Presence } \\
\text { of } \mathrm{TiO}_{2} \text { in } \\
\text { the } \\
\text { particles }\end{array}$ & $\begin{array}{l}\text { Partic } \\
\text { les } \\
\text { free } \\
\text { from } \\
\mathrm{TiO}_{2}\end{array}$ \\
\hline P1 & $\mathrm{N}$ & 2 & $\mathrm{~N}$ & $\mathrm{~N}$ & $\overline{\mathrm{N} / \mathrm{A}}$ & $\mathrm{N} / \mathrm{A}$ & $\mathrm{N} / \mathrm{A}$ & $\mathrm{N} / \mathrm{A}$ & N/A \\
\hline P2 & $\mathrm{N}$ & 2 & $Y$ & - & - & + & + & $Y$ & $\mathrm{~N}$ \\
\hline $\mathrm{P} 1$ & $\mathrm{~N}$ & 2 & $\mathrm{~N}$ & $\mathrm{~N}$ & $\mathrm{~N} / \mathrm{A}$ & $\mathrm{N} / \mathrm{A}$ & $\mathrm{N} / \mathrm{A}$ & $\mathrm{N} / \mathrm{A}$ & N/A \\
\hline P2 & $\mathrm{N}$ & 2 & $Y$ & ++ & ++ & + & + & $Y$ & $Y$ \\
\hline
\end{tabular}

\section{STEM results:}

STEM image analysis of a cluster of particles collected after abrasion of an aged P2 paint allows for identifying those chemical elements which are homogeneously present from those who aren't. A specimen which was selected because of high range of divers objects has been submitted to scan accumulation during $2124 \mathrm{~s}$.

For example, the STEM spectra show a widespread presence of $\mathrm{Ti}, \mathrm{O}, \mathrm{Zn}, \mathrm{S}$ on the collected objects. However, Si and Al are overrepresented at the left center of the image called Si Ka1 and Al Ka1 (see parts surrounded by a red line), where a debris from the substrate aluminosilicate brick is located. The image thus identifies i) a composite (high concentration of $\mathrm{Si}, \mathrm{O}$ and $\mathrm{Al}$ ), ii) NOAAs of $\mathrm{P} 2$ (micronic and submicronic quasi-spheres mainly composed of $\mathrm{Ti}, \mathrm{Si}, \mathrm{O}, \mathrm{Zn}$ see e.g. surrounded zone by a blue line in the Figure 14, iii) nanometric objects with $\mathrm{O}$ prevailing the presence of $\mathrm{Si}, \mathrm{Zn}$, and $\mathrm{Ti}$, latter ones covering the whole mesh (see e.g. surrounded zone by a black line in the Figure 14).

Si (e.g. see surrounded zone by a white line in the Si Ka1 elemental mapping of Figure 15) and, to a lesser extent, Zn (e.g. see surrounded zone by a white line in Zn Ka1 elemental mapping of Figure 15) are largely present in the form of isolated particles or 
nano-scaled NOAA. Ti is mainly present in the form of micronic NOAAs and less frequently submicronic NOAAs (e.g. see surrounded zone by a green line in the Ti Ka1 elemental mapping of Figure 15). The rare presence of particles containing Ti shows the presence of free nano- $\mathrm{TiO}_{2}$ or as nanometric NOAA (e.g. see surrounded zone by a yellow line in the Ti Ka1 elemental mapping of Figure 15).

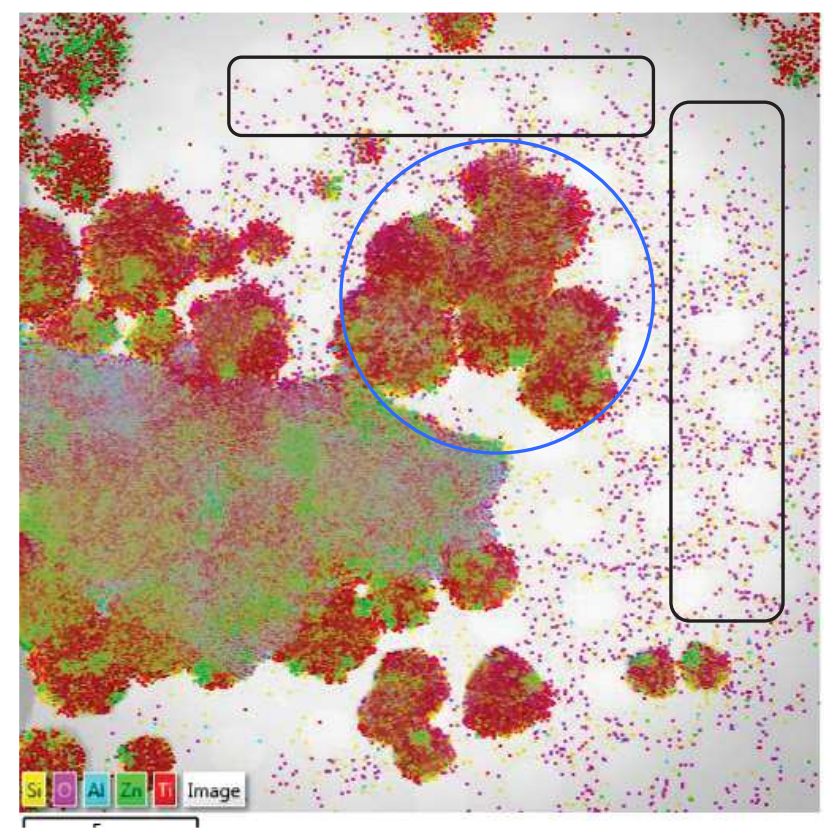

Figure 14: overlaying of elemental mapping ( $\mathrm{Ti}, \mathrm{Si}, \mathrm{O}, \mathrm{Al}, \mathrm{Zn}, \mathrm{S}$ ) obtained by STEM images of collected particles NOAA and composites of P2 abrasion test. Ti, Si, O, Al, Zn. Livetime 2124 s, Accelerating Voltage: $120.00 \mathrm{kV}$, Specimen Tilt (degrees): 20.0 , Elevation (degrees): 10.5, Number of Channels: 2048, Energy Range (keV): $20 \mathrm{keV}$, Energy per Channel (eV): $10.0 \mathrm{eV}$.

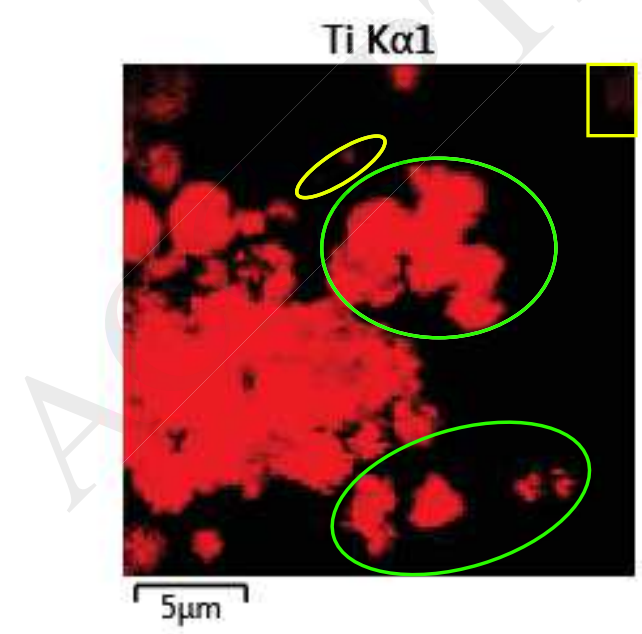



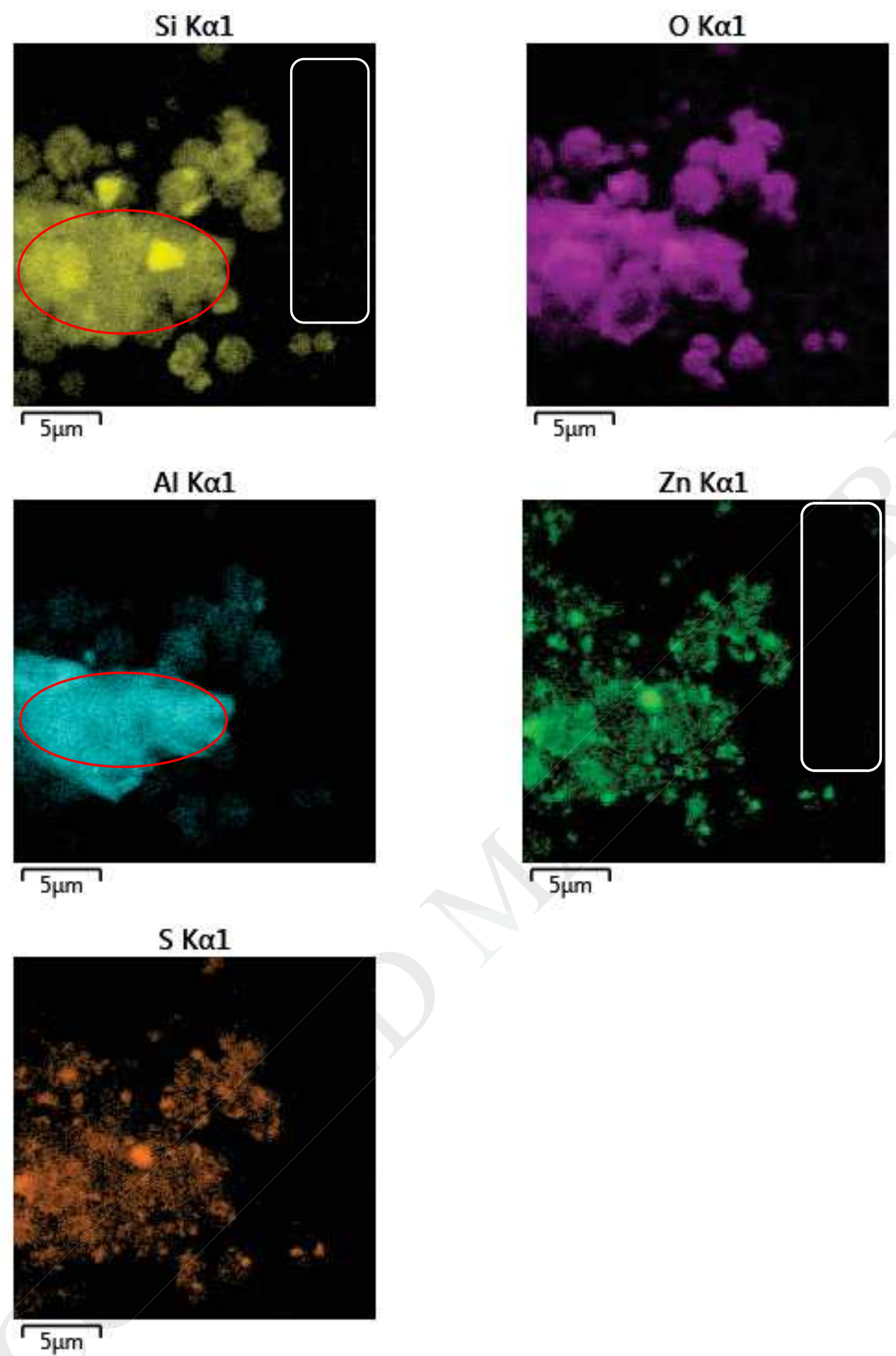

Figure 15 : separated elemental mappings ( $\mathrm{Ti}, \mathrm{Si}, \mathrm{O}, \mathrm{Al}, \mathrm{Zn}, \mathrm{S}$ ) from Figure 14 with the same collected particles NOAA and composites of P2 after abrasion test. Livetime $2124 \mathrm{~s}$, accelerating voltage: $120.00 \mathrm{kV}$, specimen tilt (degrees): 20.0, elevation (degrees): 10.5 , number of channels: 2048, energy range $(\mathrm{keV})$ : $20 \mathrm{keV}$, energy per channel $(\mathrm{eV})$ : $10.0 \mathrm{eV}$.

\section{Discussion}

Two paints by the same manufacturer containing nano- $\mathrm{TiO}_{2}$ were subjected to the same abrasion test. Emissions from unweathered samples of paints $\mathrm{P} 2$ are low and made up of 
composites (Table 4). Weathered paint $\mathrm{P} 2$ containing nano- $\mathrm{TiO}_{2}$ has a high emissivity of free NP and NOAA, while P1, does not give off emissions after weathering. The Table 4 highlights that emissions from surface layer abrasion of paints are correlated to primary particle sizes or NOAA generated by spraying. The distortion between the mobility diameter of weathered P2 under abrasion and the size of the NOAA's (14 nm) of P2 could be explained by i) the difference of measurement between SMPS and TEM, ii) the presence of $\mathrm{SiO}_{2}$ or matrix debris for SMPS measurement which change and shift the main peak to $21 \mathrm{~nm}$ instead of $14 \mathrm{~nm}$. 
Table 4: summary of the nature of obtained emissions for the tested nanomaterials.

\begin{tabular}{|c|c|c|c|c|c|c|c|c|c|c|}
\hline $\begin{array}{l}\text { Sample } \\
\text { code }\end{array}$ & $\begin{array}{l}\text { Size } \\
(\mathrm{nm}) \text { of } \\
\text { the } \\
\text { primary } \\
\text { particle }\end{array}$ & $\begin{array}{l}\text { Principal } \\
\text { (nm) mode of } \\
\text { dispersion } \\
\text { before } \\
\text { introduction. } \\
\text { Secondary } \\
\text { mode(s) in } \\
\text { italics }\end{array}$ & $\begin{array}{ll}5 & \text { Co } \\
& \text { mpo } \\
& \text { sitio } \\
& \mathrm{n} \\
& \mathrm{mg} / \\
& \mathrm{L} \text { by } \\
\mathrm{TX} \\
\mathrm{RF} .\end{array}$ & $\begin{array}{l}\text { Surface } \\
\text { Depositi } \\
\text { on (SD) } \\
\text { or } \\
\text { Introduc } \\
\text { ed into } \\
\text { the } \\
\text { Matrix } \\
\text { (IM) }\end{array}$ & $\begin{array}{l}\text { Free NP } \\
\text { emissio } \\
\text { ns } \\
\text { observe } \\
\text { d before } \\
\text { weatheri } \\
\text { ng (No- } \\
\text { Yes) }\end{array}$ & $\begin{array}{l}\text { Free NP } \\
\text { emissio } \\
\mathrm{n} \\
\text { observe } \\
\mathrm{d} \text { after } \\
\text { weatheri } \\
\text { ng. (No- } \\
\text { Yes) }\end{array}$ & $\begin{array}{l}\text { Free } \\
\text { NOAA } \\
\text { emissio } \\
n \\
\text { observe } \\
\text { d before } \\
\text { weatheri } \\
\text { ng. (No- } \\
\text { Yes) }\end{array}$ & $\begin{array}{l}\text { Free } \\
\text { NOAA } \\
\text { emissio } \\
n \\
\text { observe } \\
d \quad \text { after } \\
\text { weatheri } \\
\text { ng }\end{array}$ & $\begin{array}{l}\text { Compos } \\
\text { ite } \\
\text { emissio } \\
n \\
\text { observe } \\
d \text { before } \\
\text { weatheri } \\
\text { ng }\end{array}$ & $\begin{array}{l}\text { Compos } \\
\text { ite } \\
\text { emissio } \\
\mathrm{n} \\
\text { observe } \\
\mathrm{d} \text { after } \\
\text { weatheri } \\
\mathrm{ng}\end{array}$ \\
\hline P1 & 20 & 32 & $\begin{array}{l}\text { Ti: } \\
1034.7 \\
\text { Si: } \\
451.4 \\
\text { K : } 19.0\end{array}$ & SD & $\mathrm{N}$ & $\mathrm{N}$ & $\mathrm{N}$ & $\mathrm{N}$ & $\mathrm{N}$ & $\mathrm{N}$ \\
\hline P2 & 8 & $116 ; 402$ & $\begin{array}{l}\text { Ti: } \\
926.3 ; \\
\text { Si: } \\
\text { 1437.3; } \\
\text { Zn: } \\
131.3\end{array}$ & SD & $\mathrm{N}$ & $Y$ & $\mathrm{~N}$ & $Y$ & $Y$ & $Y$ \\
\hline
\end{tabular}


Weathering can favour free NP discharge from façade coatings (Shandilya et al., 2015). Our trials confirmed this point and complemented it with information on paint; one of our tested samples emitted by abrasion free nano- $\mathrm{TiO}_{2}$, something which had not been described previously (Göhler et al., 2016; Kaiser et al., 2013). A comparison between sprayed NOAA of $\mathrm{P} 2$ and release NOAA of weathered P2 highlights the huge weathering effects on this paint: the agglomerate forms $\mathrm{P} 2$ are easily visible after weathering.

Even if nano- $\mathrm{TiO}_{2}$ concentrations were not actually discernible by our measurement techniques due to the presence of pigmentary $\mathrm{TiO}_{2}$ in these paints, it seems unlikely that a simple concentration modification is the only explanation for P2 emissivity after weathering. Indeed, nano- $\mathrm{TiO}_{2}$ has not been identified up until this day as being capable of weakening paint (Miklečić et al., 2015).

The difference in emissivity between paints $\mathrm{P} 1$ and $\mathrm{P} 2$ is probably related to the great difference in their chemical formulation (Table 2). Indeed, paint P2 is highly spiked with silicon $(1.44 \mathrm{~g} / \mathrm{L})$, whereas $P 1$ contains practically three times less $(0.45 \mathrm{~g} / \mathrm{L})$. The presence of zinc (131 mg/L) in P2 and its absence in P1 must be underlined.

Moreover, even if emissive paint P2 has a higher concentration of $\mathrm{Si}$, to our knowledge no compound containing silicon is known for its capacity to degrade a paint after weathering. However, the presence of $\mathrm{ZnO}$ in P2 can cause greater fragility in a layer of paint. Indeed, Miklecic et al. recently described the alteration of paints in the loss of long-lasting and tension resistance properties after weathering when nano-ZnO are present (Miklečić et al., 2015). Weakening of paints during weathering due to the presence of $\mathrm{Zn}$ can thus explain the observed changes in mechanical properties and subsequently the emissivity of paint P2.

Further studies are needed to establish more precisely the different causes which lead to P2 fragilities after weathering and make possible a nanosafer paint production.

\section{Conclusion}

Abrasion tests about both 7-month weathered paints containing nano- $\mathrm{TiO}_{2}$. One of them releases mainly submicronic of nanosized NOAA's of titanium dioxide in presence free nano$\mathrm{TiO}_{2}$. The free release of nanosized NOAA's and free nano- $\mathrm{TiO}_{2}$ confirmed by TEM and STEM analysis. The SMPS size distribution of abrasion test about emissive paint is dominated by a peak at $21 \mathrm{~nm}$ and is consistent with NOAA's and nano- $\mathrm{TiO}_{2}$. Distinction between nano-pigment nano- $\mathrm{TiO}_{2}$, NOAA's of $\mathrm{TiO}_{2}$ is possible with STEM and highlights the nano-pigment or the nano-SiO${ }_{2}$ domination on the samples with respect to photocatalytic nano- $\mathrm{TiO}_{2}$. Microscopy makes possible otherwise the identification of some paint/brick composites.

Since the release is observed for one of the two paints, the formulation of the emissive paint is under question. The weathering effects on paints depend on the compounds used during the design. Without excluding the impacts of the small size of nano- $\mathrm{TiO}_{2}$ on the weathering, the presence of $\mathrm{Zn}$ in the paint and absent in the non-emissive paint, is a possible cause of the releases. It could be consistent with literature which identifies $\mathrm{Zn}$ as a cause of greater fragility in paint. Moreover, this work highlights the need of weathering $s$ to establish the paint emissivity after weathering which may be crucial to characterize a realistic exposure assessment in the future. The free release of nano- $\mathrm{TiO}_{2}$ or nano- $\mathrm{SiO}_{2}$ in the air could have a clear impact for health and environment. Complementary studies are required to improve the knowledge on the topic and identify the process which lead to a higher emissivity with certain paints. 


\section{Acknowledgments}

The authors would like to thank the French Ministry of Environment (Program 190), ANSES (Nanodata Project, APR ANSES 2012), the DAMPEC funding scheme of Sorbonne Universités allowing for working in a network and the EUPLAPSCH team. Experimental work of Morgane Dalle is gratefully acknowledged.

\section{8 references}

Al-Kattan, A., Wichser, A., Vonbank, R., Brunner, S., Ulrich, A., Zuin, S., Arroyo, Y., Golanski, L., Nowack, B., 2015. Characterization of materials released into water from paint containing nano-SiO2. Chemosphere 119, 1314-1321.

Al-Kattan, A., Wichser, A., Zuin, S., Arroyo, Y., Golanski, L., Ulrich, A., Nowack, B., 2014. Behavior of $\mathrm{TiO}(2)$ released from Nano-TiO(2)-containing paint and comparison to pristine Nano-TiO(2). Environ Sci Technol 48, 6710-6718.

Bartolomei, V., Sorgel, M., Gligorovski, S., Alvarez, E.G., Gandolfo, A., Strekowski, R., Quivet, E., Held, A., Zetzsch, C., Wortham, H., 2014. Formation of indoor nitrous acid (HONO) by light-induced NO2 heterogeneous reactions with white wall paint. Environ Sci Pollut Res 21, 9259-9269.

Bressot, C., Aubry, A., Pagnoux, C., Aguerre Chariol, O., Morgeneyer, M., 2018. Assessment of functional nano-materials in medical applications: Can time mend public and occupational health risks related to the products' fate? Accepted. Journal of Toxicology and Environmental Health, Part A: Current Issues

Bressot, C., Manier, N., Pagnoux, C., Aguerre-Chariol, O., Morgeneyer, M., 2017. Environmental release of engineered nanomaterials from commercial tiles under standardized abrasion conditions. Journal of Hazardous Materials 322, 276-283.

Chapman, J., Sullivan, T., Regan, F., 2012. Nanoparticles in Anti-microbial Materials : Use and Characterisation. Royal Society of Chemistry, Cambridge, U.K.

CPS Instruments Europe, 2004. http://www.cpsinstruments.eu/pdf/Manual.pdf.

Daigle, C.C., Chalupa, D.C., Gibb, F.R., Morrow, P.E., Oberdorster, G., Utell, M.J., Frampton, M.W., 2003. Ultrafine particle deposition in humans during rest and exercise.

De La Calle, I., Cabaleiro, N., Romero, V., Lavilla, I., Bendicho, C., 2013. Sample pretreatment strategies for total reflection X-ray fluorescence analysis: A tutorial review. Spectrochimica Acta Part B: Atomic Spectroscopy 90, 23-54.

Donaldson, K., Poland, C.A., 2013. Nanotoxicity: challenging the myth of nano-specific toxicity. Current Opinion in Biotechnology 24, 724-734.

Elsaesser, A., Howard, C.V., 2012. Toxicology of nanoparticles. Advanced Drug Delivery Reviews 64, 129-137.

Froggett, S.J., Clancy, S.F., Boverhof, D.R., Canady, R.A., 2014. A review and perspective of existing research on the release of nanomaterials from solid nanocomposites. Particle \& Fibre Toxicology 11, $1-28$.

Göhler, D., Stintz, M., Rommert, A., 2016. Im Lack und drum herum. Partikelfreisetzung beim Umgang mit nanostrukturierten Materialien. Farbe und Lack 122, 52-60.

Gomez, V., Levin, M., Saber, A.T., Irusta, S., Dal Maso, M., Hanoi, R., Santamaria, J., Jensen, K.A., Wallin, H., Koponen, I.K., 2014. Comparison of dust release from epoxy and paint nanocomposites and conventional products during sanding and sawing. Ann Occup Hyg 58, 983-994.

Gregory, J., 2005. Particles in Water : Properties and Processes. CRC Press, London.

Handy, R.D., Shaw, B.J., 2007. Toxic effects of nanoparticles and nanomaterials: Implications for public health, risk assessment and the public perception of nanotechnology. Health, Risk \& Society 9 , 125-144.

Hincapie, I., Caballero-Guzman, A., Hiltbrunner, D., Nowack, B., 2015. Use of engineered nanomaterials in the construction industry with specific emphasis on paints and their flows in construction and demolition waste in Switzerland. Waste management 43, 398-406. 
Hong, F., Yu, X., Wu, N., Zhang, Y.-Q., 2017. Progress of in vivo studies on the systemic toxicities induced by titanium dioxide nanoparticles. Toxicol. Res. 6, 115-133.

Kaegi, R., Sinnet, B., Zuleeg, S., Hagendorfer, H., Mueller, E., Vonbank, R., Boller, M., Burkhardt, M., 2010. Release of silver nanoparticles from outdoor facades. Environ Pollut 158, 2900-2905.

Kaegi, R., Ulrich, A., Sinnet, B., Vonbank, R., Wichser, A., Zuleeg, S., Simmler, H., Brunner, S., Vonmont, H., Burkhardt, M., Boller, M., 2008. Synthetic TiO2 nanoparticle emission from exterior facades into the aquatic environment. Environ Pollut 156, 233-239.

Kaiser, J.P., Zuin, S., Wick, P., 2013. Is nanotechnology revolutionizing the paint and lacquer industry? A critical opinion. Sci Total Environ 442, 282-289.

Larue, C., Castillo-Michel, H., Sobanska, S., Trcera, N., Sorieul, S., Cecillon, L., Ouerdane, L., Legros, S., Sarret, G., 2014. Fate of pristine $\mathrm{TiO} 2$ nanoparticles and aged paint-containing $\mathrm{TiO} 2$ nanoparticles in lettuce crop after foliar exposure. J Hazard Mater 273, 17-26.

Lazaridis, M., Serfozo, N., Chatoutsidou, S.E., Glytsos, T., 2015. New particle formation events arising from painting materials in an indoor microenvironment. Atmospheric Environment 102, 86-95.

Le Bihan O., Morgeneyer M., Shandilya N., Aguerre-Chariol O., C, B., 2014. Handbook on Safe Use of Nanomaterials: Chapter 9.2 - Emission chambers, a method for nanosafety,, in: Elsevier Inc., A.P., San Diego, California, USA, 2014 (Ed.).

Mahl, D., Diendorf, J., Meyer-Zaika, W., Epple, M., 2011. Possibilities and limitations of different analytical methods for the size determination of a bimodal dispersion of metallic nanoparticles. Colloids and Surfaces A: Physicochemical and Engineering Aspects 377, 386-392.

Maynard, A.D., Aitken, R.J., Butz, T., Colvin, V., Donaldson, K., Oberdorster, G., Philbert, M.A., Ryan, J., Seaton, A., Stone, V., Tinkle, S.S., Tran, L., Walker, N.J., Warheit, D.B., 2006. Safe handling of nanotechnology. Nature 444, 267-269.

Mikkelsen, L., Jensen, K.A., Koponen, I.K., Saber, A.T., Wallin, H., Loft, S., Vogel, U., Moller, P., 2013. Cytotoxicity, oxidative stress and expression of adhesion molecules in human umbilical vein endothelial cells exposed to dust from paints with or without nanoparticles. Nanotoxicology 7, 117134.

Miklečić, J., Blagojević, S.L., Petrič, M., Jirouš-Rajković, V., 2015. Influence of TiO2 and ZnO nanoparticles on properties of waterborne polyacrylate coating exposed to outdoor conditions. Progress in Organic Coatings 89, 67-74.

Mitrano, D.M., Motellier, S., Clavaguera, S., Nowack, B., 2015. Review of nanomaterial aging and transformations through the life cycle of nano-enhanced products. Environment International 77, 132-147.

Morgeneyer M., S.N., Chen Y-M., Le Bihan O., 2014. Use of a modified Taber abrasion apparatus for investigating the complete stress state during abrasion and in-process wear particle aerosol generation. Chem Eng Res Des.

Morose, G., 2010. The 5 principles of "Design for Safer Nanotechnology". Journal of Cleaner Production 18, 285-289.

Nakanishi, J., Gamo, M., 2016. Risk assessment of manufactured nanomaterials: Titanium dioxide (TiO2). Final report issued on July 22, 2011. New Energy and Industrial Technology Development Organization (NEDO) project (P06041) "Research and Development of Nanoparticle Characterization Methods." National Institute of Advanced Industrial Science and Technology (AIST). .

NF EN ISO 16474-1, 2014. NF EN ISO 16474-1 Peintures et vernis - Méthodes d'exposition à des sources lumineuses de laboratoire - Partie 1 : lignes directrices générales. AFNOR, 16747-1 : Paints and varnishes - Methods of exposure to laboratory light sources - Part 1: General guidance, p. 36. NIOSH 2011, NIOSH Current intelligence bulletin 63: occupational exposure to titanium dioxide. NIOSH (DHHS) Publication No. 2011-160. U.S. Department of Health and Human Services, Centers for Disease Control and Prevention, National Institute for Occupational Safety and Health, Cincinnati, http://www.cdc.gov/niosh/docs/2011-160/pdfs/2011-160.pdf.

Piccinno, F., Gottschalk, F., Seeger, S., Nowack, B., 2012. Industrial production quantities and uses of ten engineered nanomaterials in Europe and the world. Journal of Nanoparticle Research 14, 1-11. 
Pirela, S.V., Lu, X., Miousse, I., Sisler, J.D., Qian, Y., Guo, N., Igor, K., Castranova, V., Thomas, T., Godleski, J., Demokritou, P., 2015. Effects of Intratracheally Instilled Laser Printer-Emitted Engineered Nanoparticles on Murine Biological Responses: A Case Study of Toxicological Implications from Nanomaterials Released During Consumer Use. Nanolmpact 1, 1-8.

Poland, C.A., Duffin, R., Kinloch, I., Maynard, A., Wallace, W.A.H., Seaton, A., Stone, V., Brown, S., MacNee, W., Donaldson, K., 2008. Carbon nanotubes introduced into the abdominal cavity of mice show asbestos-like pathogenicity in a pilot study. Nat Nanotechnol 3, 423-428.

Saber, A.T., Koponen, I.K., Jensen, K.A., Jacobsen, N.R., Mikkelsen, L., Moller, P., Loft, S., Vogel, U., Wallin, H., 2012. Inflammatory and genotoxic effects of sanding dust generated from nanoparticlecontaining paints and lacquers. Nanotoxicology 6, 776-788.

Scheringer, M., Praetorius, A., Goldberg, E.S., 2014. Chapter 3 - Environmental Fate and Exposure Modeling of Nanomaterials, in: Jamie, R.L., Eugenia, V.-J. (Eds.), Frontiers of Nanoscience. Elsevier, pp. 89-125.

Shandilya, N., Le Bihan, O., Bressot, C., Morgeneyer, M., 2015. Emission of titanium dioxide nanoparticles from building materials to the environment by wear and weather. Environ Sci Technol 49, 2163-2170.

Shi, H., Magaye, R., Castranova, V., Zhao, J., 2013. Titanium dioxide nanoparticles: a review of current toxicological data. Part Fibre Toxicol 10, 15.

Towett, E.K., Shepherd, K.D., Cadisch, G., 2013. Quantification of total element concentrations in soils using total X-ray fluorescence spectroscopy (TXRF). Sci Total Environ 463-464, 374-388.

Zuin, S., Gaiani, M., Ferrari, A., Golanski, L., 2013. Leaching of nanoparticles from experimental water-borne paints under laboratory test conditions. Journal of Nanoparticle Research 16, 1-17. 